\title{
Alteration of oestrous cycle length, ovarian function and oxytocin-induced release of prostaglandin F-2 $\alpha$ by intrauterine and intramuscular administration of recombinant bovine interferon- $\alpha$ to cows
}

\author{
C. Plante*, W. W. Thatcher and P. J. Hansen $\dagger$
}

Dairy Science Department, University of Florida, IFAS 0701, Gainesville, FL 32611-0701, USA

\begin{abstract}
Summary. An experiment was conducted to (i) determine whether administration of recombinant bovine interferon- $\alpha_{1} 1(\mathrm{rBoIFN}-\alpha)$ attenuates oxytocin-induced release of prostaglandin $\mathrm{F}-2 \alpha$ and (ii) confirm previous observations that $\mathrm{rBoIFN}-\alpha$ causes acute changes in body temperature and circulating concentrations of progesterone. Cows were treated twice a day from Day 14 to Day 17 after oestrus with a control regimen (bovine serum albumin (BSA), i.m. + BSA intrauterine (i.u.)), rBoIFN- $\alpha$, i.u. + BSA, i.m. (rBoIFN-IU) or rBoIFN- $\alpha$, i.m. + BSA, i.u. (rBoIFN-IM). On Day 17, plasma concentrations of 13,14-dihydro,15-keto-prostaglandin F-2 $\alpha$ (PGFM) were measured after injection of oxytocin. Cows treated with rBoIFN-IU and rBoIFN-IM had longer oestrous cycles and luteal lifespans than control cows. A hyperthermic response and decline in plasma concentrations of progesterone was noticed after administration of rBoIFN- $\alpha$ on Day 14. On other days, the hyperthermic response was not present and the decline in progesterone was less pronounced. There was no significant effect of rBoIFN- $\alpha$ on circulating concentrations of oestradiol between Days 14 and 17. The release of PGFM induced by oxytocin was lower in cows treated with rBoIFN- $\alpha$ than in control cows. Oxytocin caused increased plasma concentrations of PGFM in four of five control cows, two of five rBoIFN-IU cows and two of five rBoIFN-IM cows. The peak PGF-2 $\alpha$ response to oxytocin (peak value after injection minus mean concentration before injection) was $257.8 \pm 61.3 \mathrm{pg} / \mathrm{ml}$ for control cows, $100 \cdot 7 \pm 40.8 \mathrm{pg} / \mathrm{ml}$ for rBoIFN-IU and $124.9 \pm 40.4 \mathrm{pg} / \mathrm{ml}$ for rBoIFN-IM. It is concluded that rBoIFN- $\alpha$ can reduce oxytocin-induced PGFM release and may therefore extend the lifespan of the corpus luteum by interfering with events leading to luteolytic release of PGF from the uterus. Administration of rBoIFN- $\alpha$ can cause acute changes in body temperature and circulating concentrations of progesterone that become less severe after repeated exposure to $\mathrm{rBoIFN}-\alpha$.
\end{abstract}

Keywords: interferon; endometrium; prostaglandin F-2a; oestrous cycle; corpus luteum; cow

\section{Introduction}

Bovine trophoblast protein-1 (bTP-1) and ovine TP-1 (oTP-1) are proteins secreted in large quantity by Day 15-22 bovine conceptuses (Helmer et al., 1987, 1989a; Plante et al., 1990) and by Day 13-21 ovine conceptuses (Godkin et al., 1982), respectively. These proteins are antiluteolytic

*Present address: Department of Pathology, Ontario Veterinary College, University of Guelph, Guelph, Ontario N1G 2Wl, Canada.

$\nmid$ Reprint requests. 
and probably act by depressing endometrial prostaglandin F-2 $\alpha$ (PGF-2 $\alpha$ ) secretion (Godkin et al., 1984; Helmer et al., 1989a, b). They are members of the alpha-interferon family (Imakawa et al., 1987, 1989; Stewart et al., 1987, 1989; Charpigny et al., 1988) and possess antiviral and immunosuppressive activity characteristic of other interferon (IFN) molecules (Pontzer et al., 1988; Newton et al., 1989; Plante et al., 1990).

It is likely that non-embryonic IFN- $\alpha$ s can simulate the antiluteolytic effect of bTP-1 and oTP-1 when given to cyclic animals. Administration of recombinant bovine interferon- $\alpha_{1} 1(\mathrm{rBoIFN}-\alpha)$ in utero or intramuscularly on Days 14-21 to cycling cows prolonged interoestrous interval and corpus luteum (CL) lifespan (Plante et al., 1988, 1989; Newton et al., 1990). In sheep, continuous intrauterine infusion of rBoIFN- $\alpha$ from Day 9 to Day 19 extended luteal lifespan and reduced circulating concentrations of PGF-2 $\alpha$ metabolite (Stewart et al., 1989). Also, human interferon- $\alpha$ inhibited secretion of PGF- $2 \alpha$ by ovine endometrial cells (Salamonsen et al., 1988, 1989) and nonembryonic interferons suppressed prostaglandin synthesis in other tissues (Dore-Duffy et al., 1983; Boraschi et al., 1985; Browning \& Ribolini, 1987).

Other reports indicate that interferons reduce circulating concentrations of steroid hormones. In women, administration of interferon- $\alpha$ reduced oestradiol and progesterone concentrations in blood (Kaupilla et al., 1982); in men, testosterone concentrations in serum were diminished after injection of interferon- $\alpha$ (Orava et al., 1986). Pretreatment with interferon- $\alpha$ reduced human chorionic gonadotrophin (hCG)-stimulated testosterone secretion from cultured porcine Leydig cells (Orava, 1989). Intramuscular injection of rBoIFN- $\alpha$ can also cause an acute decline in circulating concentrations of progesterone in heifers, as well as inducing hyperthermia (Newton et al., 1990). This hyperthermia could have additional consequences on endocrine and reproductive function (Biggers et al., 1987; Putney et al., 1988).

In the present study, it was evaluated whether intramuscular and intrauterine administration of rBolFN- $\alpha$ extends luteal lifespan by reducing uterine release of PGF- $2 \alpha$. This was examined by testing the hypothesis that administration of $\mathrm{rBoIFN}-\alpha$ reduces release of PGF- $2 \alpha$ from the uterus in response to oxytocin. Secretion of PGF- $2 \alpha$ from endometrium was monitored by measuring peripheral concentrations of 13,14-dihydro, 15-keto-PGF-2 $\alpha$ (PGFM), a stable metabolite of PGF$2 \alpha$ that is a reliable indicator of PGF-2 $\alpha$ release from uterine tissues (Kindahl et al., 1976). McCracken et al. $(1981,1984)$ hypothesized, using the sheep as an experimental model, that ovarian oestradiol acts to trigger luteolysis by increasing synthesis of endometrial oxytocin receptors. Subsequently, oxytocin, presumably secreted by the corpus luteum (CL) in cattle (Wathes et al., 1983), binds to these receptors to stimulate PGF- $2 \alpha$ release. During early pregnancy in cattle, endometrial release of PGF- $2 \alpha$ is attenuated in response to oestrogen (Thatcher et al., 1984) and oxytocin (Lafrance \& Goff, 1985). Similar PGF responses were observed following an oestradiol injection on Day 18 of the oestrous cycle in cows receiving intrauterine infusion of conceptus secretory proteins (Knickerbocker et al., 1986). Effects of rBolFN- $\alpha$ on circulating progesterone and oestradiol- $17 \beta$ concentrations, follicular status at Day 17 after oestrus and body temperature were also ascertained to evaluate potential side-effects.

\section{Materials and Methods}

\footnotetext{
Materials. Recombinant $\mathrm{rBoIFN}-\alpha$ and placebo for rBoIFN were donated by CIBA-GEIGY (Basle, Switzerland). The amount of endotoxin contamination in $\mathrm{rBoIFN}-\alpha$ preparations was 0.5 endotoxin units/mg protein or less, as determined by the Amebocyte Lysate Test (Food and Drug Administration, 1987) and was similar to endotoxin amounts in placebo. Bovine serum albumin (fraction V), heparin and penicillin-streptomycin were purchased from Sigma Chemical Co. (St Louis, MO, USA). Dulbecco's phosphate-buffered saline (D-PBS) was obtained from Gibco (Grand Island, NY, USA). Lutalyse was from Upjohn Co. (Kalamazoo, MI, USA), and oxytocin from Vedco Company (Arcadia, CA, USA). Artificial insemination straws of $0.5 \mathrm{ml}$ were purchased from IMV (Minneapolis, MN, USA). The artificial insemination gun with one terminal opening on the plastic sheath, as well as the second protective plastic sheaths, were from Nasco (Fort Atkinson, WI, USA). Linear scanning ultrasound (LS-300 Ultrasound Diagnostic System) with a $7.5 \mathrm{MHz}$ probe was from Tokyo Reiki Co., Ltd (Tokyo, Japan).
} 
Preparation of $r B o I F N-a$. Intrauterine solutions of $r B o L F N-\alpha$ were prepared as a $10 \mathrm{mg} / \mathrm{ml}$ solution in a commercial carrier buffer (placebo) containing $5 \mathrm{mg}$ bovine serum albumin (BSA)/ml. For controls, a solution of $15 \mathrm{mg}$ $\mathrm{BSA} / \mathrm{ml}$ dissolved in placebo was prepared. These two solutions were loaded into $0.5 \mathrm{ml}$ artificial insemination straws. For each straw, $200 \mu$ of the respective solution was aspirated into the middle of the straw. The bolus was bracketed between air bubbles that, in turn, were bracketed between $100 \mu \mathrm{l}$-PBS containing $100 \mathrm{iu}$ penicillin $/ \mathrm{ml}$ and $100 \mu \mathrm{g}$ streptomycin $/ \mathrm{ml}$. Intramuscular injection solutions were composed of $2.5 \mathrm{mg} \mathrm{rBoIFN}-\alpha / \mathrm{ml}$ or $2.5 \mathrm{mg} \mathrm{BSA} / \mathrm{ml}$ dissolved in the placebo solution.

Administration of $r$ BoIFN-a. Twenty-five non-lactating dairy cows were palpated rectally, and those possessing a functional $\mathrm{CL}$ were injected with $25 \mathrm{mg}$ lutalyse. Cows were checked three times a day for behavioural oestrus. Fifteen cows ( 12 Holstein and three Jersey) exhibiting oestrus were assigned randomly to receive one of three treatments (five cows/treatment) from Day 14 to Day 17 of the oestrous cycle. Control cows received $3.0 \mathrm{mg}$ BSA/intrauterine infusion and $10.0 \mathrm{mg} \mathrm{BSA} /$ intramuscular injection. In the second group (rBoIFN-IU), cows received both in-utero infusion of $2.0 \mathrm{mg} \mathrm{rBoIFN-} \alpha$ supplemented with $1.0 \mathrm{mg}$ BSA/infusion and intramuscular injection of $10 \mathrm{mg}$ BSA/ injection. The third group (rBoIFN-IM) received intrauterine infusion of $3.0 \mathrm{mg}$ BSA/infusion and intramuscular

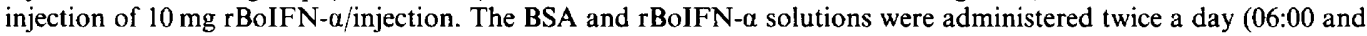
$18: 00 \mathrm{~h}$ ) so that the total daily dose of rBoIFN- $\alpha$ was 4 and $20 \mathrm{mg}$ for rBoIFN-IU and rBoIFN-IM, respectively. Intrauterine infusions were performed as described by Plante et al. $(1988,1989)$; approximately half of the infusing solution was deposited in the right horn and the other half in the left horn.

Oestrus detection and blood collection. Animals were observed for oestrus three times a day (07:00, 12:00 and 19:00 h) beginning on Day 14 of the oestrous cycle. Blood samples $(20 \mathrm{ml})$ were collected from coccygeal vessels into heparinized vacutainer tubes, twice a day $(05: 30$ and 12:00 h) from Day 14 to Day 17, and once a day (morning) from Day 18 to oestrus. In addition, at 09:00 h on Day 17, cows were fitted with a 14 gauge, jugular cannula (Abbott, North Chicago, IL, USA) $5 \cdot 5$ inches long connected to an intravenous extension set (Cole-Palmer, Chigago, IL, USA). The cannula was flushed with heparinized saline $(200 \mathrm{units} / \mathrm{ml})$ after each sampling to prevent occlusion. Frequent blood sampling $(20 \mathrm{ml})$ was performed every $15 \mathrm{~min}$ for $1 \mathrm{~h}$ before $(10: 00$ to 11:00 h) and $2 \mathrm{~h}$ after $(11: 00$ to 13:00 h) an oxytocin challenge (100 units, i.v. in $5 \mathrm{ml}$ ) at 11:00 h. An additional sample was obtained 5 min after oxytocin $(1 \mathrm{l}: 05 \mathrm{~h})$. All samples were placed in heparinized tubes $(25 \mathrm{U})$, put on ice and the plasma collected within $1 \mathrm{~h}$ by centrifugation at $2000 \mathrm{~g}$ for $15 \mathrm{~min}$. Plasma was aspirated and stored at $-20^{\circ} \mathrm{C}$ until radioimmunoassay.

Radioimmunoassay. Plasma samples were assayed for progesterone as described by Knickerbocker et al. (1986). The intra-assay and interassay coefficients of variation (CV) for three assays were 8.7 and $3.8 \%$, respectively. Plasma collected from Day 14 to oestrus was also analysed for oestradiol concentrations by a previously validated radioimmunoassay (Guilbault et al., 1987). The intra-assay and interassay CV was 7.9 and $16.8 \%$, respectively. Plasma samples obtained on Day $17(10: 00$ to 13:00 h) were analysed for PGFM by an assay described by Guilbault et al. (1984). The intra-assay and interassay CV was 8.2 and $15 \cdot 6 \%$, respectively.

Ovarian ultrasound. Real-time linear scanning ultrasonic examination was performed at 08:00 h on Day 17. Before examination, faecal material was removed from the rectum. The transducer was then inserted rectally and moved laterally over the ovaries to examine ovarian sequential sections for follicular populations. Size and occurrence of follicles $>3 \mathrm{~mm}$ were recorded.

Body temperature measurements. Rectal temperatures were measured at 05:30, 09:00, 12:00 and 17:30 h on Day 14 and at 05:50 and 12:00 h from Day 15 to Day 17.

Statistical analysis. Data were analysed by least-squares analysis of variance using the General Linear Models procedure of the Statistical Analysis System (SAS, 1985). Interoestrus intervals and duration of functional luteal lifespan (interval between the first day of oestrus and the day when serum concentration of progesterone first fell below $1 \mathrm{ng} / \mathrm{ml}$ ) were analysed with treatment as the only effect in the model. Orthogonal contrasts were used to compare rBoIFN-treated cows with control cows and to compare rBoIFN-IU with rBoIFN-IM. Data on oestradiol and progesterone concentrations and rectal temperature were analysed considering effects of treatment, cow (treatment), day, day $\times$ treatment, day $\times$ cow (treatment), time, treatment $\times$ time, time $\times$ cow (treatment), day $\times$ time and treatment $x$ day $\times$ time.

Data for rectal temperature readings on Day 14 and PGFM concentrations on Day 17 (10:00 to 11:00 h preoxytocin samples and 11:00 to 13:00 h post-oxytocin samples analysed separately) were analysed using split-plot analyses of variance with repeated measurements over time and a model with effects of treatment, cow(treatment), time, treatment $\times$ time and time $\times$ cow(treatment). Because of the heterogeneity of variance among treatments, PGFM data were transformed using square roots prior to analysis. Tests of homogeneity of regression of postinjection data were performed to describe whether rBoIFN- $\alpha$ altered time trends in PGFM concentrations from 11:00 to $13: 00 \mathrm{~h}$. As an additional test of whether rBoIFN- $\alpha$ altered basal concentrations of PGFM and the PGFM response to oxytocin, analyses were performed to determine whether the between-animal variance in time trends (determined in large part by the response to oxytocin) differed between treatments. For each treatment group, untransformed data for PGFM were analysed by least-squares analysis of variance using model components of cow, time and cow $\times$ time. The $F$ tests for heterogeneity of cow $\times$ time variance for each treatment comparison (i.e. control vs. IM, control vs. IU, IM vs. IU) were calculated as the ratio of mean squares for cow $\times$ time. These tests for heterogeneity of variance were performed for the entire sampling period on Day 17, to determine whether treatment affected between-animal variance in time-trends in response to oxytocin and, for the pre-injection values only, to 
determine whether treatment affected between-animal variation in time trends of basal PGFM concentrations. As an additional test of whether treatment affected PGFM increase after oxytocin, the peak PGFM response (highest postinjection concentration minus mean pre-injection PGFM concentration) and the average PGFM response (mean post-injection concentration minus mean pre-injection concentration) were calculated for each animal. Treatment differences were evaluated by least-squares analysis of variance using orthogonal contrasts to compare interferon-treated cows to control cows and to compare rBoIFN-IM to rBoIFN-IU.

Data on the size of the largest follicle were analysed considering treatment as the only main effect. Follicles identified by ultrasound were also categorized as class 1,2 or 3 by having a diameter of $3-5,6-9$ and $>9 \mathrm{~mm}$, respectively. Number of follicles was analysed either by least-squares analysis of variance, using effects of treatment, cow(treatment), class and treatment $\times$ class, or by the CATMOD procedure (SAS, 1985), considering effects of treatment, class and treatment $\times$ class. Data were analysed as one data set and as a subset of class 2 and 3 follicles only.

\section{Results}

\section{Effects of rBoIFN on interoestrous interval, corpus luteum lifespan and pro-oestrus interval}

Intrauterine (IU) or intramuscular (IM) administration of rBoIFN- $\alpha$ to cyclic cows from Day 14 to Day 17 extended length of the oestrous cycle $(22 \cdot 6,25 \cdot 0$ and $27 \cdot 0$ for control, rBoIFN-IU and rBoIFN-IM, respectively; pooled s.e.m. $=0.57 ; P<0.001)$ and CL lifespan $(21.8,24.0$ and 25.4 days for control, rBoIFN-IU and rBoIFN-IM, respectively; pooled s.e.m. $=0.77 ; P<0.02$ ) compared with cows receiving BSA. Cows treated with rBoIFN- $\alpha$ intramuscularly had a longer interoestrous interval $(P<0.03)$ than cows treated with $\mathrm{rBoIFN}-\alpha$ in utero, but $\mathrm{CL}$ lifespan did not differ as a result of route of $\mathrm{BBOIFN}-\alpha$ administration.

\section{Effects of rBoIFN- $\alpha$ on body temperature}

Body temperature from Day 14 to Day 17 (Fig. 1) was affected by a treatment $\times$ time $\times$ day interaction $(P<0.005)$. These effects resulted because both types of rBoIFN- $\alpha$ administration caused an acute increase in body temperature on Day 14, peak values occurring at $6 \mathrm{~h}$ after administration. Intramuscular $\mathrm{rBoIFN}-\alpha$ administration was more pyrogenic than intrauterine infusion $(P<0.01)$. On other days examined, $\mathrm{rBoIFN}-\alpha$ had no effect on body temperature.

\section{Effects of rBolFN- $\alpha$ on plasma progesterone}

A treatment $\times$ time $\times$ day interaction $(P<0.005)$ affected progesterone concentrations from Day 14 to Day 17 (Fig. 1). At Day 14, rBoIFN-IM caused an acute decrease in progesterone coinciding with the increase in body temperature. On Day 15 , an $\mathrm{rBoIFN}$-associated progesterone decrease was again noticed for rBoIFN-IM, but was not as pronounced as at Day 14. Concentrations of progesterone dropped slightly after rBoIFN-IM administration on Days 16 and 17.

\section{Effects of rBoIFN- $\alpha$ on ovarian characteristics}

Means for size of the largest follicle on Day 17 were 10.2, 11.6 and $11.6 \mathrm{~mm}$ (pooled s.e.m. $=1.23$ ) for control, rBoIFN-IU and rBolFN-IM treated cows, respectively. Average numbers of follicles per cow classified in class 1,2 and 3 were $7 \cdot 00,0 \cdot 80$ and $0 \cdot 60$ for control cows; $4 \cdot 20,1.80$ and 1.00 for rBoIFN-IU-treated cows; and 5.20, 1.00 and 1.40 for cows receiving rBoIFN-IM (pooled s.e.m. $=0.78$ ). Treatments or treatment $\times$ class effects were not significant as analysed by either least-squares analysis of variance or CATMOD. Oestradiol-17 $\beta$ concentrations were not affected by any main effects or interactions (Fig. 1). 


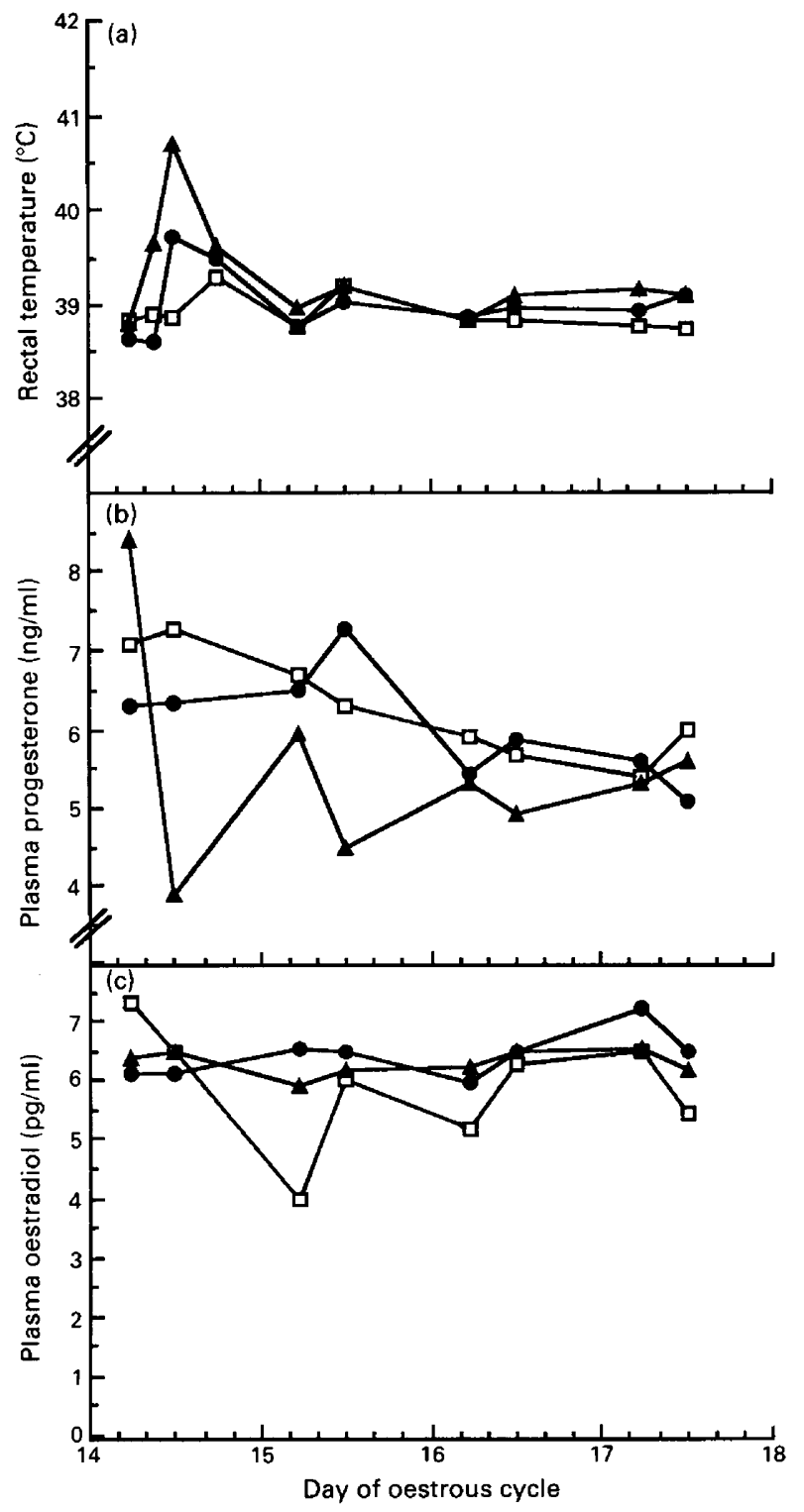

Fig. 1. Effect of intrauterine (i.u.) and intramuscular (i.m.) administration of rBoIFN- $\alpha$ on (a) rectal temperature and (b) progesterone and (c) oestradiol-17 $\beta$ concentrations. Lines represent control cows receiving a bovine serum albumin solution ( $0 \mathrm{mg}$ IFN, $\square$ ), or cows receiving $2 \mathrm{mg}$ rBoIFN- $\alpha$ i.u. (O) or $10 \mathrm{mg}$ rBoIFN- $\alpha$ i.m. (A). (a) Body temperature from Day 14 to Day 17 was affected by treatment $(P<0.005)$, day $(P<0.001)$, treatment $\times$ time $(P<0.03)$, day $\times$ time $(P<0.001)$ and treatment $\times$ time $\times$ day $(P<0.005)$. Analysis of data from Day 14 demonstrated that rBoIFN- $\alpha$ induced a hyperthermic effect in treated cows $(P<0.01)$. Adminstration of rBoIFN- $\alpha$ i.m. was more pyrogenic than i.u. administration $(P<0.01)$. Pooled s.e.m. $=0 \cdot 12$. (b) Concentrations of progesterone were affected by time $(P<0.005)$, day $\times$ time $(P<0.03)$ and treatment $\times$ time $\times$ day $(P<0.005)$. Pooled s.e.m. $=0.46$. (c) Oestradiol concentrations were not affected by any main effects or interactions. Pooled s.e.m. $=0.56$. 


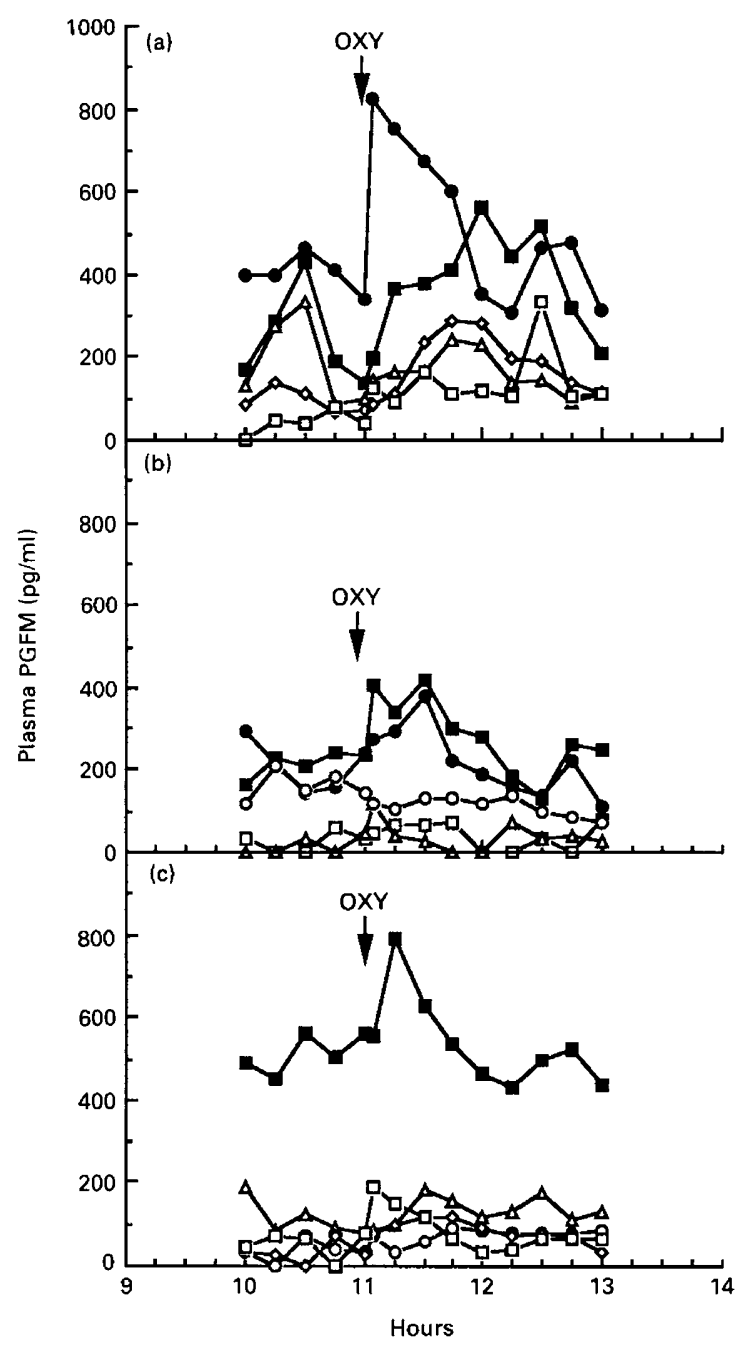

Fig. 2. Individual profiles of plasma 13,14-dihydro,15-keto-prostaglandin F-2 $\alpha$ (PGFM) from

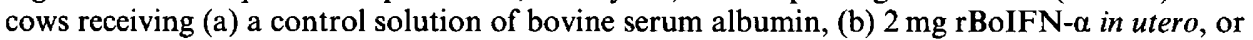
(c) $10 \mathrm{mg}$ rBoIFN- $\alpha$ intramuscularly. Cows were challenged at 11:00 h of Day 17 after oestrus with $100 \mathrm{U}$ of oxytocin (OXY). Based on heterogeneity of variation analysis, PGFM concentrations before the oxytocin challenge (10:00-11:00 h) displayed more between-time variation in control cows than in cows treated with rBoIFN- $\alpha$ i.u. $(P<0 \cdot 10)$ or i.m. $(P<0.05)$. Oxytocin increased PGFM concentrations $(P<0.001)$. The peak and average PGFM response to oxytocin were greater $(P<0.05)$ for control cows than for cows treated with rBoIFN- $\alpha$. Heterogeneity of regression $(P<0.01)$ indicated that the increase in PGFM due to oxytocin was lower for cows treated with rBoIFN- $\alpha$ than for control cows. According to analysis of variance, responses for cows receiving rBoIFN- $\alpha$ i.u. or i.m. were not different.

\section{Effects of rBoIFN- $a$ on oxytocin-induced release of PGFM}

Based on analysis of variance and heterogeneity of regression analyses on untransformed or transformed data, mean plasma concentrations of PGFM (Fig. 2) were not statistically different between groups before or after oxytocin injections. Before oxytocin injection, the between-animal variance in time trends (i.e. variance due to cow $\times$ time) was less for cows receiving rBoIFN-IU 
Table 1. Summary of analysis for heterogeneity of regression in response curves over time for plasma concentrations of 13,14-dihydro, 15-keto-prostaglandin F- $2 \alpha$ in cows after injection of oxytocin on Day $17^{\mathrm{a}}$

\begin{tabular}{|c|c|c|c|c|c|c|c|c|c|c|c|}
\hline \multicolumn{6}{|c|}{ Model 1} & \multicolumn{6}{|c|}{ Model 2} \\
\hline Source & d.f. & $\mathrm{SS}^{b}$ & $\mathbf{M S}^{\mathfrak{c}}$ & $F$ & $P$ & Source & d.f. & SS & MS & $F$ & $P$ \\
\hline Total & 149 & 5628 & & & & Total & 149 & 5628 & & & \\
\hline $\begin{array}{l}\text { Treatment } \\
\text { Cow }\end{array}$ & 2 & 675 & 337.5 & $1 \cdot 1^{d}$ & $0 \cdot 38$ & Treatment & 2 & 675 & $337 \cdot 5$ & $1 \cdot 1^{d}$ & 0.38 \\
\hline $\begin{array}{l}\text { Cow } \\
\text { (treatment) }\end{array}$ & 12 & 3847 & $320 \cdot 6$ & $46 \cdot 5$ & $0 \cdot 001$ & $\begin{array}{l}\text { Cow } \\
\text { (treatment) }^{d}\end{array}$ & 12 & 3847 & $320 \cdot 6$ & $51 \cdot 7$ & 0.001 \\
\hline Time & 1 & 28 & 28.0 & $4 \cdot 1$ & 0.05 & Trt $\times$ time & 3 & 68 & $22 \cdot 7$ & $3 \cdot 7$ & 0.014 \\
\hline Time $^{2}$ & 1 & 56 & $56 \cdot 0$ & $8 \cdot 1$ & 0.005 & Trt $\times$ time $^{2}$ & 3 & 163 & $54 \cdot 3$ & $8 \cdot 8$ & 0.001 \\
\hline Time $^{3}$ & 1 & 52 & 52.0 & $7 \cdot 5$ & 0.007 & Trt $\times$ time $^{3}$ & 3 & 53 & $17 \cdot 7$ & 2.9 & 0.040 \\
\hline Time $^{4}$ & 1 & 62 & $62 \cdot 0$ & $9 \cdot 0$ & 0.004 & Trt $\times$ time $^{4}$ & 3 & 64 & $21 \cdot 3$ & $3 \cdot 4$ & 0.018 \\
\hline Residual & 131 & 908 & 6.9 & & & Residual & 123 & 758 & $6 \cdot 2$ & & \\
\hline \multicolumn{12}{|c|}{ Calculation of $F$ for heterogeneity of regression } \\
\hline & Res & lual d.f. & $\mathrm{SS}$ & MS & $F$ & $P$ & & & & & \\
\hline Model 1 & & 131 & 908 & & & & & & & & \\
\hline Model 2 & & 123 & 758 & $6 \cdot 2$ & & & & & & & \\
\hline Difference & & 8 & 150 & $18 \cdot 8$ & $3 \cdot 0$ & 0.01 & & & & & \\
\hline
\end{tabular}

${ }^{a}$ Data analysed were hormone concentrations collected from 0 to $2 \mathrm{~h}$ after oxytocin administration. Data were transformed using square roots prior to analysis.

${ }^{\mathrm{b} S S}$ (sums of squares); 'MS (mean squares); ${ }^{\mathrm{d}}$ treatment effect tested using cow (treatment) as the error term.

$(P<0.10)$ and rBoIFN-IM $(P<0.05)$ than for controls. This was so because treatment with rBoIFN- $\alpha$ lowered between-cow differences in variability in PGFM concentrations, perhaps because pulsatile release of PGF- $2 \alpha$ from the uterus was reduced.

After oxytocin, there was an overall increase in PGFM concentrations (time effect, $P<0.001$ ). Inspection of individual profiles indicated that oxytocin increased PGFM concentrations for four of five control cows, two of five cows treated with rBoIFN-IU and two of five cows treated with rBoIFN-IM. The peak PGFM response to oxytocin for control cows $(257.8 \pm 61 \cdot 3 \mathrm{pg} / \mathrm{ml})$ was greater $(P<0.05)$ than for cows treated with rBoIFN- $\alpha(100 \cdot 7 \pm 40.8 \mathrm{pg} / \mathrm{ml}$ for rBoIFN-IU and $124.9 \pm 40.4 \mathrm{pg} / \mathrm{ml}$ for rBoIFN-IM). Differences between $\mathrm{rBoIFN}$-IU and rBoIFN-IM were not significant. Average PGFM response to oxytocin $(84 \cdot 8 \pm 28 \cdot 8$ for control cows, $14.1 \pm 19 \cdot 5 \mathrm{pg} / \mathrm{ml}$ for rBoIFN-IU and $34.3 \pm 5.9 \mathrm{pg} / \mathrm{ml}$ for rBoIFN-IM; control versus rBoIFN- $\alpha, P<0.05$; rBoIFN-IU versus rBoIFN-IM, non-significant) was similar.

Regression analysis of values from 0 to $120 \mathrm{~min}$ after injection indicated that response curves for rBoIFN-treated animals were different from those of controls (heterogeneity of regression, $P<0.01$; see Table 1). The between-animal variance in time trends over the entire sampling period (i.e. variance due to cow $\times$ time) was less for cows receiving rBolFN- $\alpha$ than for controls $(P<0.05)$, because of treatment effects on response to oxytocin. In the controls, most animals responded and there was considerable between-cow variability in the pattern of response over time. The between-cow variability in time trends was small for cows treated with rBoIFN- $\alpha$ because most cows had stable and low concentrations of PGFM over time.

\section{Discussion}

In agreement with previous results (Plante et al., 1988, 1989; Newton et al., 1990), intramuscular and intrauterine administration of rBoIFN- $\alpha$ extended interoestrous interval and CL lifespan. Results suggest that luteal maintenance may have involved changes in uterine release of PGF-2 $\alpha$, as 
oxytocin-induced PGFM was reduced in most cases in IFN-treated cows. This is similar to the situation in early pregnancy (Days 14-17) when endometrial release of PGF-2 $\alpha$ induced by oestradiol (Thatcher et al., 1984) and oxytocin (Lafrance \& Goff, 1985; Putney et al., 1989) is attenuated. It is probable that conceptus interferon also reduces prostaglandin secretion as intrauterine infusion of conceptus secretory proteins from Day 15.5 to Day 21 reduced oestradiol-induced PGFM concentrations on Day 18 of the cycle (Knickerbocker et al., 1986). Furthermore, bTP-1 (Helmer et al., 1989b) and other interferons (Salamonsen et al., 1988, 1989) reduced PGF-2 $\alpha$ secretion from cultured endometrium. In the current study, concentrations of PGFM before oxytocin were similar among rBoIFN- $\alpha$ treated and control cows. Similarly, pregnant and cyclic cows at Days 17-19 do not differ in PGFM concentrations prior to an oxytocin (Lafrance \& Goff, 1985; Putney et al., 1988) challenge. The failure to find an effect on average basal concentrations of PGFM when an effect on oxytocin-induced release was found reflects that experiments were not designed to test for effects on basal secretion. None the less, the reduction in within-animal variation of preinjection concentrations of PGFM caused by administration of rBoIFN- $\alpha$ suggests that basal release of PGF- $2 \alpha$ was altered.

Of interest in the current study was the finding that some of the cows treated with rBolFN- $\alpha$ had high basal concentrations of PGFM and responded markedly to oxytocin. Cycle length was extended in these cows and it is not known why they failed to show clear suppression of PGFM concentrations. One possibility is that other actions of rBoIFN- $\alpha$ may also promote extension of corpus luteum function. In the present study, possible effects of $\mathrm{rBoIFN}-\alpha$ on ovarian follicles were examined. The ovarian follicular population has been shown to play an important role in luteolysis as destruction of the follicular population around Days 9-15 of the oestrous cycle extends luteal lifespan (Hughes et al., 1987). As interferons can reduce circulating concentration of oestradiol-17 $\beta$ in women (Kaupilla et al., 1982), it is possible that $\mathrm{rBoIFN}-\alpha$ delays luteolysis by suppressing follicles that initiate luteolysis. An intensive survey of follicular growth was not carried out, but there were no significant effects of rBoIFN- $\alpha$ on follicular characteristics at Day 17 or on oestradiol-17 $\beta$ concentrations from Day 14 to Day 17.

In the present study, rBoIFN- $\alpha$ induced an acute pyrogenic effect, with peak hyperthermia at $6 \mathrm{~h}$ after administration. This effect was not seen after subsequent injections. As expected, the intramuscular injection of $\mathrm{rBoIFN}-\alpha$ was more pyrogenic than intrauterine infusion, probably because of dose differences ( $10 \mathrm{vs} .2 \mathrm{mg}$ ). A significant decline in serum concentrations of progesterone in cows treated with rBoIFN-IM coincided with the peak of hyperthermia at Day 14. Other depressions in progesterone concentrations caused by rBoIFN-IM were seen on Days 15-17, though of lower magnitude than on Day 14 and not temporally associated with hyperthermia. An acute effect of intramuscular injection of $r B o I F N-\alpha$ on circulating progesterone concentrations has also been reported elsewhere (Newton et al., 1990). In the studies of Plante et al. (1989), no inhibitory effects of $\mathrm{rBoIFN}-\alpha$ on serum concentrations of progesterone were observed. This is not surprising because progesterone concentrations were measured $12 \mathrm{~h}$ or more after administration of rBoIFN- $\alpha$, when they would have returned to values similar to those before injection (Newton et al., 1990).

From the present study and the literature (Kaupilla et al., 1982; Orava et al., 1986; Orava, 1989), it is clear that interferons can depress circulating concentrations of certain steroids when administered intramuscularly. In particular, rBoIFN- $\alpha$ has two distinct effects on progesterone concentrations in cows (Plante et al., 1988, 1989; Newton et al., 1990; present results). First, rBoIFN- $\alpha$ extends the lifespan of the corpus luteum, probably through its actions on endometrial prostaglandin release. Secondly, rBoIFN- $\alpha$ causes a short-term $(6-8 \mathrm{~h})$ depression in circulating concentrations of progesterone that probably occurs through mechanisms distinct from effects of rBoIFN- $\alpha$ on luteal lifespan. This latter effect of rBoIFN- $\alpha$ is reduced after repeated exposure to rBoIFN- $\alpha$.

Although the possible use of $\mathrm{rBoIFN}-\alpha$ to increase fertility in cattle by acting in an antiluteolytic support role is plausible, the pyrogenic effects manifested by rBoIFN- $\alpha$, as well as the depression 
in serum concentrations of progesterone, could be detrimental to the development of an early embryo. Embryos recovered from heat-stressed cows between Days 8 and 16 of pregnancy were smaller than those from control cows (Biggers et al., 1987). In addition, Day 17 conceptuses, heat stressed in vitro, secreted less bTP-1 than thermoneutral embryos (Putney et al., 1988). Recent studies in sheep, however, indicated that rBolFN- $\alpha$ increases pregnancy rate (Nephew et al., 1990; Maurer \& Hansen, 1991; Schalue-Francis et al., 1991). Perhaps side-effects of rBoIFN- $\alpha$ are different in sheep and cattle, or perhaps the side-effects themselves are not sufficient to override positive effects of rBoIFN- $\alpha$.

Research supported by USDA (85-CRCR-1871-1 and 89-37240) and CIBA-GEIGY, Basle, Switzerland. The authors thank M. Leslie for valuable technical support, D. Hissem for managing animals and M. E. Hissem for preparing the manuscript. This is Journal Series No. R-00662 of the Florida Agricultural Experiment Station.

\section{References}

Biggers, B.G., Geisert, R.P., Wettemann, R.P. \& Buchanon, D.S. (1987) Effect of heat stress on early embryonic development in the beef cow. J. Anim. Sci. 64, 1512-1518.

Boraschi, D., Censini, S., Bartalini, M. \& Tagliabue, A. (1985) Regulation of arachidonic acid metabolism in macrophages by immune and nonimmune interferons. J. Immunol. 135, 502-505.

Browning, J.L. \& Ribolini, A. (1987) Interferon blocks interleukin 1 -induced prostaglandin release from human peripheral monocytes. J. Immunol. 138, 2857-2863.

Charpigny, G., Reinaud, P., Huet, J.-C., Guillomot, M., Charlier, M., Pernollet, J.-C. \& Martal, J. (1988) High homology between a trophoblastic protein (trophoblastin) isolated from ovine embryos and $\alpha$-interferons. FEBS Lett. 228, 12-16.

Dore-Duffy, P., Perry, w. \& Kua, H.H. (1983) Interferon-mediated inhibition of prostaglandin synthesis in human mononuclear leukocytes. Cell. Immunol. 79, 232-239.

Food and Drug Administration. (1987) Guideline on validation of the Limulus Amebocyte Lysate test as an end-product endotoxin test for human and animal parenteral drugs, biological products, and medical devices. Food and Drug Administration, Rockville, MD.

Godkin, J.D., Bazer, F.W., Moffatt, J., Sessions, F. \& Roberts, R.M. (1982) Purification and properties of a major, low molecular weight protein released by the trophoblast of sheep blastocysts at Day 13-21. J. Reprod. Fert. 65, 141-150.

Godkin, J.D., Bazer, F.W., Thatcher, W.W. \& Roberts, R.M. (1984) Proteins released by cultured Day 15-16 conceptuses prolong luteal maintenance when introduced into the uterine lumen of cyclic ewes. $J$. Reprod. Fert. 71, 57-64.

Guilbault, L.A., Thatcher, W.W., Drost, M. \& Hopkins, S.M. (1984) Source of F series prostaglandins during the early postpartum period in cattle. Biol. Reprod. 31, 879-887.

Guilbault, L.A., Thatcher, W.W. \& Wilcox, C.J. (1987) Influence of a physiological infusion of prostaglandin $F_{2 u}$ into postpartum cows with partially suppressed endogenous production of prostaglandins. 2. Interrelationships of hormonal, ovarian and uterine responses. Theriogenology 27, 947-957.

Helmer, S.D., Hansen, P.J., Anthony, R.V., Thatcher, W.W., Bazer, F.W. \& Roberts, R.M. (1987) Identification of bovine trophoblast protein-1, a secretory protein immunologically related to ovine trophoblast protein-1. J. Reprod. Fert. 79, 83-91.

Helmer, S.D., Hansen, P.J., Thatcher, W.W., Johnson, J.W. \& Bazer, F.W. (1989a) Intrauterine infusion of highly enriched bovine trophoblast protein-1 complex exerts an antiluteolytic effect to extend corpus luteum lifespan in cyclic cattle. J. Reprod. Fert. 87, 89-101.

Helmer, S.D., Gross, T.S., Hansen, P.J. \& Thatcher, W.W. (1989b) Bovine trophoblast protein-1 complex alters endometrial protein and prostaglandin synthesis and induces an intracellular inhibitor of prostaglandin synthesis in vitro. J. Reprod. Fert. 87, $421-430$.

Hughes, T.L., Villa-Godoy, A., Kesner, J.S. \& Fogwell, R.L. (1987) Destruction of bovine ovarian follicles: effects on the pulsatile release of luteinizing hormone and prostaglandin $\mathrm{F}_{2 a}$-induced luteal regression. Biol. Reprod. 36, 523-529.

Imakawa, K., Anthony, R.V., Kazemi, M., Marotti, K.R., Polites, H.G. \& Roberts, R.M. (1987) Interferon-like sequence of ovine trophoblast protein secreted by embryonic trophectoderm. Nature (Lond.) 330, 377-379.

Imakawa, K., Hansen, T.R., Malathy, P.V., Anthony, R.V., Polites, H.G., Marotti, K.R. \& Roberts, R.M. (1989) Molecular cloning and characterization of complementary deoxyribonucleic acids corresponding to bovine trophoblast protein-1 and bovine interferon- $\alpha_{11}$. Mol. Endocr. 3, 127-139.

Kaupilla, A., Cantell, K., Janne, O., Kokko, E. \& Vihko, R. (1982) Serum sex steroid and peptide hormone concentration, and endometrial estrogen and progestin receptor levels during administration of human leukocyte interferon. Int. J. Cancer 29, 291-294.

Kindahl, H., Edqvist, L.E., Bane, A. \& Granstrom, E. (1976) Blood levels of progesterone and 
15-keto-13,14-dihydro prostaglandin $F_{2 a}$ during the normal estrous cycle and early pregnancy in heifers. Acta Endocr. 82, $134-139$.

Knickerbocker, J.J., Thatcher, W.W., Bazer, F.W., Barron, D.H. \& Roberts, R.M. (1986) Inhibition of uterine prostaglandin- $F_{2 u}$ production by bovine conceptus secretory proteins. Prostaglandins 31, 777-793.

Lafrance, M. \& Gofi, A.K. (1985) Effect of pregnancy on oxytocin-induced release of prostaglandin $\mathrm{F}_{2 \alpha}$ in heifers. Biol. Reprod. 33, 1113-1119.

Maurer, R.R. \& Hansen, P.J. (1991) Survival of whole and demi-embryos in ewes given bovine interferon- $\alpha$. FASEB J. 5, A680 (abstr.).

McCracken, J.A., Schramm, W., Barcikowski, B. \& Wilson, L.J. (1981) The identification of prostaglan$\operatorname{din} \mathrm{F}_{2 a}$ as a uterine luteolytic hormone and the hormonal identification of its synthesis. Acta Vet. Scand., Suppl. 77, 71-88.

McCracken, J.A., Schramm, W., \& Okulicz, W.C. (1984) Hormone receptor control of pulsatile secretion of $\mathrm{PGF}_{2 \alpha}$ from the ovine uterus during luteolysis and its abrogation in early pregnancy. Anim. Reprod. Sci. 7, 31-88.

Nephew, K.P., McClure, K.E., Day, M.L., Xie, S., Roberts, R.M. \& Pope, W.F. (1990) Effects of intramuscular administration of recombinant bovine interferon-alpha 1 during the period of maternal recognition of pregnancy. J. Anim. Sci. 68, 2766-2771.

Newton, G.R., Vallet, J.L., Hansen, P.J. \& Bazer, F.W. (1989) Inhibition of lymphocyte proliferation by ovine trophoblast protein-1 and a high molecular weight glycoprotein produced by the peri-implantation sheep conceptus. Am. J. Reprod. Immunol. 19,99-107.

Newton, G.R., Martinod, S., Hansen, P.J. Thatcher, W.W., Siegenthaler, B., Gerber, C. \& Voirol, M.-J. (1990) Effect of bovine interferon on acute changes in body temperature and serum progesterone concentration in heifers. J. Dairy Sci. 73, 3439-3448.

Orava, M. (1989) Comparison of the inhibitory effects of interferons- $\alpha$ and $-\gamma$ on testosterone production in the porcine Leydig cell culture. J. Interferon Res. 9, $135-141$.

Orava M., Cantell, K. \& Vihko, R. (1986) Treatment with preparations of human leukocyte interferon decreases serum testosterone concentrations in men. Int. J. Cancer. 38, 295-296.

Plante, C., Hansen, P.J. \& Thatcher, W.W. (1988) Prolongation of luteal function in cows by intrauterine infusion of recombinant bovine alpha-interferon. Endocrinology 122, 2342-2344.

Plante, C., Hansen, P.J., Martinod, S., Siegenthaler, B., Thatcher, W.W., Pollard, J. \& Leslie, M.V. (1989) Effect of intrauterine and intramuscular administration of recombinant bovine interferon $\alpha_{1}$ on luteal lifespan in cattle. J. Dairy Sci. 72, 1859-1865.

Plante, C., Hansen, P.J., Thatcher, W.W., Johnson, J.W., Pollard, J.W., Mirando, M.A. \& Bazer, F.W. (1990) Purification of bovine trophoblast protein-1 complex and quantification of its microhetero- geneous variants as affected by culture conditions. $J$. Reprod. Immunol. 18, 271-291.

Pontzer, C.H., Torres, B.A., Vallet, J.L., Bazer, F.W. \& Johnson, H.M. (1988) Antiviral activity of the pregnancy recognition hormone ovine trophoblast protein-1. Biochem. Biophys. Res. Commun. 152, 801-807.

Putney, D.J., Malayer, J.R., Gross, T.S., Thatcher, W.W., Hansen, P.J. \& Drost, M. (1988) Heat-stress induced alterations in the synthesis and secretion of proteins and prostaglandins by cultured bovine conceptuses and uterine endometrium. Biol. Reprod. 39, 717-728.

Putney, D.J., Torres, C.A.A., Gross, T.S., Thatcher, W.W., Plante, C. \& Drost, M. (1989) Modulation of uterine prostaglandin biosynthesis by pregnant and nonpregnant cows at day 17 post-estrus in response to in vivo and in vitro heat stress. Anim. Reprod. Sci. 20, 31-47.

Salamonsen, L.A., Stuchbery, S.J., O'Grady, C.M., Godkin, J.D. \& Findlay, J.K. (1988) Interferon- $\alpha$ mimics effects of ovine trophoblast protein 1 on prostaglandin and protein secretion by ovine endometrial cells in vitro. J. Endocr. 117, R1-R4.

Salamonsen, L.A., Manikhot, J., Healy, D.L. \& Findlay, J.K. (1989) Ovine trophoblast protein-1 and human interferon alpha reduce prostaglandin synthesis by ovine endometrial cells. Prostaglandins 38, 289-305.

SAS (1985) SAS User's Guide, 5th ed. SAS Institute Inc., Cary, NC.

Schalue-Francis, T.K., Farin, P.W., Cross, J.C., Keisler, D. \& Roberts, R.M. (1991) The effect of injected bovine interferon- $\alpha_{1} 1$ on oestrous cycle length and pregnancy success in sheep. J. Reprod. Fert. 91, $347-356$.

Stewart, H.J., McCann, S.H.E., Barker, P.J., Lee, K.E., Lamming, G.E. \& Flint, A.P.F. (1987) Interferon sequence homology and receptor binding affinity of ovine trophoblast antiluteolytic protein. J. Endocr. 115, R13-R15.

Stewart, H.J., Flint, A.P.F., Lamming, G.E., McCann, S.H.E. \& Parkinson, T.J. (1989) Antiluteolytic effects of blastocyst-secreted interferon investigated in vitro and in vivo in the sheep. J. Reprod. Fert., Suppl. 37, 127-137.

Thatcher, W.W., Wolfenson, D., Curl, J.S., Rico, L.E., Knickerbocker, J.J., Bazer, F.W. \& Drost, M. (1984) Prostaglandin dynamics associated with development of the bovine conceptus. Anim. Reprod. Sci. 7, 149-176.

Wathes, D.C., Swann, R.W., Birkett, S.D., Porter, D.G. \& Pickering, B.T. (1983) Characterization of oxytocin, vasopressin and neurophysin from the bovine corpus luteum. Endocrinology 113, 693-698.

Received 17 September 1990 